\title{
Effects of the cardioselective beta-adrenergic receptor blocking agent metoprolol in angina pectoris Subacute study with exercise tests
}

\author{
Lars-Göran Ekelund, Anders G. Olsson, Lars Orö, and Stephan Rössner \\ From the Departments of Internal Medicine and Clinical Physiology, Karolinska Sjukhuset, Stockholm, \\ Sweden
}

The effect of a cardioselective beta-adrenergic blocking agent, metoprolol ${ }^{1}$, on symptoms and exercise tolerance was studied in 16 patients with angina pectoris.

Metoprolol was compared with placebo at two dose levels (20 $\mathrm{mg}$ t.d.s. and $50 \mathrm{mg}$ t.d.s.) in a double-blind trial in 14 patients. Compared with placebo, metoprolol caused a significant reduction of heart rate and systolic blood pressure during exercise, and consequently a reduction of the rate-pressure product. The reduction was greater with $50 \mathrm{mg}$ t.d.s. than with $20 \mathrm{mg}$ t.d.s. The exercise tolerance measured as total work increased significantly by 21 per cent during treatment with metoprolol $20 \mathrm{mg}$ t.d.s., and by 17 per cent during treatment with $50 \mathrm{mg}$ t.d.s. There was a reduction in the number of anginal attacks and in nitroglycerin consumption, and subjective improvement of angina pectoris at both dose levels of metoprolol. No signs of cardiac failure appeared during any of the four treatment periods. Heart volume showed no significant change. Unwanted effects were of the same frequency and severity during treatment with metoprolol at both dose levels as with placebo.

The sixteen patients were included in a long-term tolerance study with unchanged doses of metoprolol and have now been followed for 24 months without any unwanted effects.

In animal studies, metoprolol has been found to inhibit the heart rate and contractile force responses to isoprenaline in considerably lower doses than were required to block the vasodilator and bronchodilator effects of isoprenaline (Åblad, Carlsson, and Ek, 1973). By the criteria of Lands, Luduena, and Buzzo (1967), metoprolol selectively blocks beta ${ }_{1-}$ adrenergic receptors. Metoprolol has been found to be devoid of beta-receptor stimulating properties (Åblad et al., 1973). Compared with placebo metoprolol significantly increased the exercise tolerance in patients with angina pectoris, in an acute study reported by Adolfsson et al. (1974). In view of these findings the present study was undertaken to evaluate the effects of metoprolol in patients with angina pectoris in a subacute study.

Received 28 May 1975.

1 Metroprolol is also known as H 93/26 (AB Hässle, Sweden) and CGP 2175 (Ciba-Geigy AG, Switzerland), and is marketed in the U.K. as Betaloc (Astra) and Lopresor (Geigy).

\section{Subjects}

Sixteen patients, previously treated with a betaadrenergic blocking drug for angina pectoris for at least three months, entered the study. All had a typical history of angina pectoris by the criteria of Rose (1962). The mean age was 59 years (range 51 to 66 years), and the mean duration of angina pectoris was 6 years (range 6 months to 14 years). Nine patients had previously suffered myocardial infarction and four were treated with digoxin because of previous signs of heart failure. All patients but one had cardiac volumes within normal limits and one was at the upper limit of the normal range. Pertinent clinical information is given in Table 1.

\section{Methods}

During a run-in period of 3 weeks, the patients were treated with alprenolol $100 \mathrm{mg}$ t.d.s. This was followed by a 3-week period of treatment with placebo and a 3week period of treatment with metoprolol $20 \mathrm{mg}$ t.d.s., and subsequently by 3-week periods of treatment with placebo and metoprolol $50 \mathrm{mg}$ t.d.s. The sequence of treatment with metoprolol and placebo was randomized 
TABLE 1 Clinical findings

\begin{tabular}{|c|c|c|c|c|c|c|}
\hline $\begin{array}{l}\text { Case } \\
\text { No. }\end{array}$ & Sex & $\begin{array}{l}\text { Age } \\
(y r)\end{array}$ & $\begin{array}{l}\text { Duration of } \\
\text { angina pectoris } \\
(y r)\end{array}$ & $\begin{array}{l}\text { Supine heart } \\
\text { volume } \\
\text { (ml per } m^{2} B S A \text { ) }\end{array}$ & $\begin{array}{l}\text { Previous } \\
\text { myocardial } \\
\text { infarction }\end{array}$ & $\begin{array}{l}\text { Current treatment } \\
\text { daily }\end{array}$ \\
\hline 1 & $\mathbf{M}$ & 54 & 1 & 580 & + & Digoxin $0.25 \mathrm{mg}$, antilipaemic drug \\
\hline 2 & $\mathbf{M}$ & 60 & 3 & 330 & + & Clofibrate $2 \mathrm{~g}$, nicotinic acid $3 \mathrm{~g}$ \\
\hline 3 & $\mathbf{M}$ & 66 & 11 & 450 & + & Digoxin $0.25 \mathrm{mg}$, clofibrate $2 \mathrm{~g}$ \\
\hline 4 & $\mathbf{M}$ & 62 & 10 & 480 & - & - \\
\hline 5 & $\mathbf{F}$ & 61 & 11 & 400 & + & Clofibrate $2 \mathrm{~g}$ \\
\hline 6 & $\mathbf{F}$ & 64 & 7 & 420 & + & $\begin{array}{l}\text { Prednisolone } 5 \mathrm{mg} \text {, mepacrine } 5 \mathrm{mg} \text {, chlortha- } \\
\text { lidone } 50 \mathrm{mg}+\mathrm{KCl}\end{array}$ \\
\hline 7 & $\mathbf{M}$ & 59 & 4 & 440 & + & Clofibrate $2 \mathrm{~g}$ \\
\hline 8 & M & 60 & 8 & 440 & + & Digoxin $0.25 \mathrm{mg}$, anticoagulant \\
\hline 9 & $\mathbf{M}$ & 56 & 12 & 480 & - & Chlorthalidone $50 \mathrm{mg}+\mathrm{KCl}$, clofibrate $2 \mathrm{~g}$ \\
\hline 10 & $\mathbf{M}$ & 63 & 14 & 460 & + & Dicoumarol \\
\hline 11 & $\mathbf{M}$ & 56 & 0.5 & 460 & - & - \\
\hline 12 & $\mathbf{M}$ & 59 & 10 & 380 & + & $\begin{array}{l}\text { Chlorthalidone } 100 \mathrm{mg}+\mathrm{KCl} \text {, nicotinic acid } \\
3 \mathrm{~g}\end{array}$ \\
\hline 13 & $\mathbf{M}$ & 63 & 10 & 460 & - & Nicotinic acid $3 \mathrm{~g}$ \\
\hline 14 & $\mathbf{M}$ & 51 & 2 & No measurement & - & Nicotinic acid $3 \mathrm{~g}$, dicoumarol \\
\hline 15 & $\mathbf{M}$ & 61 & 2 & 440 & - & - \\
\hline 16 & $\mathbf{M}$ & 51 & 0.5 & 420 & - & Digoxin $0.13 \mathrm{mg}$ \\
\hline
\end{tabular}

at each dose level independently (Fig. 1). The metoprolol and placebo tablets used in this study were identical in size, shape, colour, and taste.

Patients were examined and had exercise tests at the end of each period. Laboratory tests were performed at the same times, as follows: haemoglobin, leucocyte count, platelets, ESR; serum creatinine, bilirubin, alkaline phosphatase, AST, ALT, cholesterol, triglycerides, and uric acid; plasma sodium, potassium, and bicarbonate.

\section{A. Clinical assessment}

A simple diary card, to which the patients had become accustomed during the run-in period, was completed by the patient and returned to the physician at each visit. The diary card showed the number of nitroglycerin tablets taken each day, the number of anginal attacks, and a daily subjective assessment of angina

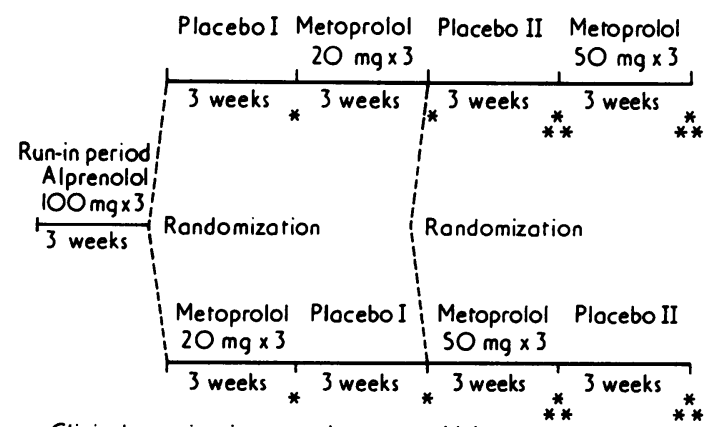

* Clinical examination, exercise tests and laboratory tests ** Heort volume in supine position

FIG. 1 Design of the study. pectoris according to a four-point scale. In addition, the patients were asked to express a general preference for each treatment period.

For statistical evaluation of the attack rate, the mean values for the 14 patients for each three-week period have been used.

\section{B. Exercise test}

Exercise tests were performed in the sitting position on an electrically braked bicycle ergometer (SiemensElema EM 380) by a standardized procedure, with stepwise increasing work loads. The exercise tests were performed with six minutes at each work load; the increments of work load were so adjusted that the patients could complete at least two six-minute exercise periods before being stopped by chest pain during the third period. Electrocardiograms were monitored continuously and recorded intermittently during exercise using six praecordial leads (chest-head).

'Perceived exertion' was estimated on a 16-point scale (Borg, 1970). Corresponding scales were constructed for grading angina pectoris, dyspnoea, and the sensation of fatigue in the legs. Blood pressure was measured using the cuff method. Before exercise, systolic and diastolic pressures were recorded with the patient in the supine position and after 8 minutes standing. During exercise, systolic blood pressure was measured during the fifth minute at each work level. Cardiac volume was measured twice in the supine position (Kjellberg, Lönroth, and Rudhe, 1951).

Statistical significance was analysed by Student's t-test or Wilcoxon's matched pairs signed ranks test for comparison of paired data (Siegel, 1956; Snedecor and Cochran, 1967). The $\chi^{2}$ test was used for evaluation of subjectively reported changes. All $\mathbf{P}$ values refer to two-tailed tests. 


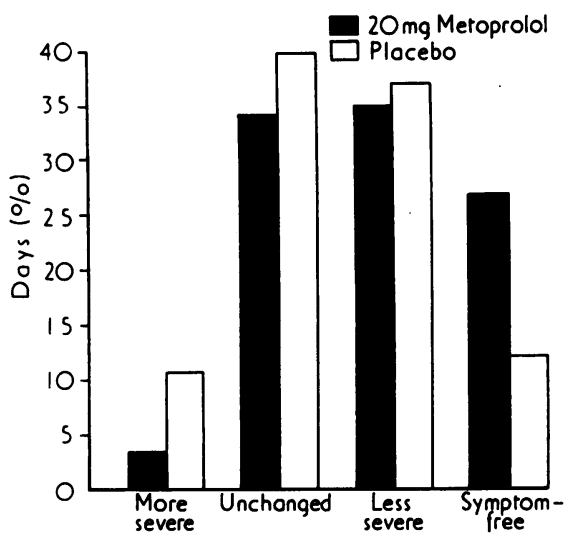

FIG. 2 Daily subjective assessment of angina pectoris (metroprolol $20 \mathrm{mg}$ t.d.s.). Statistical signifcance : $\chi^{2}=9 \cdot 84, P=0.02$.

\section{Results}

Of 16 patients entering the study, 14 completed it. Cases 15 and 16 were excluded from the evaluation as they had less than five anginal attacks a week during placebo treatment. These two patients were on treatment with metoprolol for 12 months without any unwanted effects or abnormal results of laboratory tests.

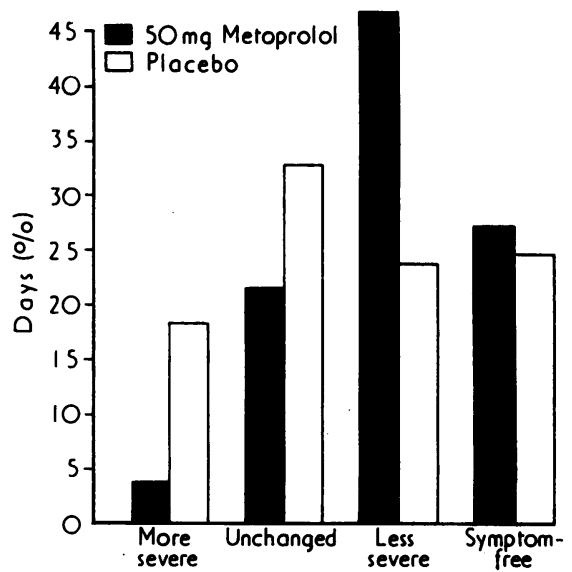

FIG. 3 Daily subjective assessment of angina pectoris (metoprolol $50 \mathrm{mg}$ t.d.s.). Statistical significance: $\chi^{2}=19.09, P<0.001$.

\section{A. Clinical assessment}

The results are given in Table 2 and Fig. 2 and 3.

Attacks per week A significant reduction in the number of attacks compared with the corresponding placebo period was achieved with metoprolol $20 \mathrm{mg}$ t.d.s. $(P<0.001)$ but not with $50 \mathrm{mg}$ t.d.s. However, it must be stressed that the two corresponding placebo periods were not identical. Cases 5,8 , and 12 had fewer anginal attacks during the second

TABLE 2 Frequency of anginal attacks and nitroglycerin consumption

\begin{tabular}{|c|c|c|c|c|c|c|c|c|}
\hline $\begin{array}{l}\text { Case } \\
\text { No. }\end{array}$ & $\begin{array}{l}\text { Attacks } \\
\text { Placebo } \\
20 \mathrm{mg}\end{array}$ & $\begin{array}{l}\text { Metoprolol } \\
20 \mathrm{mg}\end{array}$ & $\begin{array}{l}\text { Placebo } \\
50 \mathrm{mg}\end{array}$ & $\begin{array}{l}\text { Metoprolol } \\
50 \mathrm{mg}\end{array}$ & $\begin{array}{l}\text { Nitrogly } \\
\text { Placebo } \\
20 \mathrm{mg}\end{array}$ & $\begin{array}{l}\text { consumption } \\
\text { Metoprolol } \\
20 \mathrm{mg}\end{array}$ & $\begin{array}{l}\text { tablets/we } \\
\text { Placebo } \\
50 \mathrm{mg}\end{array}$ & $\begin{array}{l}\text { Metoprolol } \\
50 \mathrm{mg}\end{array}$ \\
\hline 1 & 12 & 9 & 17 & 15 & 7 & 6 & 14 & 11 \\
\hline 2 & $65^{1}$ & 23 & -2 & 16 & $39^{1}$ & 15 & -1 & 11 \\
\hline 3 & 4 & 1 & 7 & 4 & 8 & 7 & 6 & 4 \\
\hline 4 & 21 & 12 & 16 & 12 & 18 & 13 & 18 & 15 \\
\hline 5 & 8 & 4 & 3 & 4 & 1 & 4 & 1 & 2 \\
\hline 6 & 10 & 9 & 13 & 3 & 10 & 9 & 10 & 3 \\
\hline 7 & 9 & 8 & 7 & 11 & 3 & 3 & 2 & 3 \\
\hline 8 & 54 & 45 & 39 & 46 & 75 & 66 & 72 & 75 \\
\hline 9 & 20 & 16 & 26 & 29 & 67 & 57 & 80 & 76 \\
\hline 10 & 6 & 4 & 7 & 1 & 5 & 3 & 6 & 1 \\
\hline 11 & 20 & 15 & 17 & 7 & 18 & 14 & 7 & 6 \\
\hline 12 & 8 & 5 & 4 & 5 & 8 & 9 & 3 & 2 \\
\hline 14 & 15 & 12 & 10 & 8 & 11 & 8 & 6 & 4 \\
\hline $\begin{array}{l}\text { Median } \\
\text { Range }\end{array}$ & $\begin{array}{l}12 \cdot 5 \\
4-65\end{array}$ & $\stackrel{9}{1-45}$ & $\begin{array}{l}10 \\
3-39\end{array}$ & $\begin{array}{c}7 \cdot 5 \\
1-46\end{array}$ & $\stackrel{9}{1-75}$ & $\begin{array}{c}8 \cdot 5 \\
2-66\end{array}$ & $\begin{array}{c}6 \\
1-80\end{array}$ & $0^{4}-76$ \\
\hline $\mathbf{P}$ & & & & & & & & \\
\hline
\end{tabular}

${ }^{1}$ Angina worse, placebo discontinued after four days.

${ }^{2}$ Angina worse, placebo discontinued after two days. 
TABLE 3 Effect of metoprolol $20 \mathrm{mg}$ and $50 \mathrm{mg}$ on heart rate and blood pressure at rest and during exercise

\begin{tabular}{|c|c|c|c|}
\hline & Mean & $S E M$ & $P$ \\
\hline $\begin{array}{l}\text { Heart rate at rest, supine (beats/min) } \\
\text { Metoprolol } 20 \mathrm{mg}(\mathrm{n}=13) \\
\text { Placebo }\end{array}$ & $\begin{array}{l}62 \\
74\end{array}$ & $\begin{array}{l}2 \cdot 0 \\
2 \cdot 8\end{array}$ & $<0.001$ \\
\hline $\begin{array}{l}\text { Metoprolol } 50 \mathrm{mg}(\mathrm{n}=11) \\
\text { Placebo }\end{array}$ & $\begin{array}{l}58 \\
74\end{array}$ & $\begin{array}{l}2 \cdot 3 \\
2 \cdot 0\end{array}$ & $<0.001$ \\
\hline $\begin{array}{l}\text { Heart rate at comparable work load (beats } / \mathrm{min}) \\
\text { Metoprolol } 20 \mathrm{mg}(\mathrm{n}=12) \\
\text { Placebo }\end{array}$ & $\begin{array}{r}88 \\
104\end{array}$ & $\begin{array}{l}3 \cdot 5 \\
6 \cdot 1\end{array}$ & $<0.01$ \\
\hline $\begin{array}{l}\text { Metoprolol } 50 \mathrm{mg}(\mathrm{n}=11) \\
\text { Placebo }\end{array}$ & $\begin{array}{r}80 \\
103\end{array}$ & $\begin{array}{l}4 \cdot 5 \\
4 \cdot 7\end{array}$ & $<0.001$ \\
\hline $\begin{array}{l}\text { Heart rate at end of work (beats } / \mathrm{min}) \\
\text { Metoprolol } 20 \mathrm{mg}(\mathrm{n}=13) \\
\text { Placebo }\end{array}$ & $\begin{array}{r}96 \\
115\end{array}$ & $\begin{array}{l}4 \cdot 6 \\
6 \cdot 1\end{array}$ & $<0.05$ \\
\hline $\begin{array}{l}\text { Metoprolol } 50 \mathrm{mg}(\mathrm{n}=11) \\
\text { Placebo }\end{array}$ & $\begin{array}{r}90 \\
119\end{array}$ & $\begin{array}{l}4 \cdot 9 \\
6 \cdot 3\end{array}$ & $<0.001$ \\
\hline $\begin{array}{l}\text { Blood pressure at rest; supine }(\mathrm{mmHg}) \\
\text { Metoprolol } 20 \mathrm{mg}(\mathrm{n}=13) \\
\text { Placebo }\end{array}$ & $\begin{array}{l}133 / 81 \\
138 / 83\end{array}$ & $\begin{array}{l}4 \cdot 9 / 2 \cdot 6 \\
5 \cdot 2 / 2 \cdot 5\end{array}$ & $<0.05 / \mathrm{NS}$ \\
\hline $\begin{array}{l}\text { Metoprolol } 50 \mathrm{mg}(\mathrm{n}=11) \\
\text { Placebo }\end{array}$ & $\begin{array}{l}118 / 72 \\
137 / 85\end{array}$ & $\begin{array}{l}4 \cdot 2 / 2 \cdot 8 \\
5 \cdot 0 / 2 \cdot 4\end{array}$ & $<0.001 /<0.001$ \\
\hline $\begin{array}{l}\text { Systolic blood pressure at comparable work load ( } \mathrm{mmHg} \text { ) } \\
\text { Metoprolol } 20 \mathrm{mg}(\mathrm{n}=12) \\
\text { Placebo }\end{array}$ & $\begin{array}{l}154 \\
171\end{array}$ & $\begin{array}{l}7 \cdot 0 \\
8 \cdot 6\end{array}$ & $<0.05$ \\
\hline $\begin{array}{l}\text { Metoprolol } 50 \mathrm{mg}(\mathrm{n}=11) \\
\text { Placebo }\end{array}$ & $\begin{array}{l}146 \\
169\end{array}$ & $\begin{array}{l}7 \cdot 8 \\
7 \cdot 7\end{array}$ & $<0.01$ \\
\hline $\begin{array}{l}\text { Systolic blood pressure at end of work ( } \mathrm{mmHg}) \\
\text { Metoprolol } 20 \mathrm{mg}(\mathrm{n}=12) \\
\text { Placebo }\end{array}$ & $\begin{array}{l}159 \\
180\end{array}$ & $\begin{array}{l}7 \cdot 9 \\
8 \cdot 2\end{array}$ & $<0.05$ \\
\hline $\begin{array}{l}\text { Metoprolol } 50 \mathrm{mg}(\mathrm{n}=11) \\
\text { Placebo }\end{array}$ & $\begin{array}{l}160 \\
187\end{array}$ & $\begin{array}{r}7 \cdot 9 \\
10 \cdot 0\end{array}$ & $<0.01$ \\
\hline $\begin{array}{l}\text { Rate-pressure product }\left(\times 10^{-2}\right) \text {, at comparable work load } \\
\text { Metoprolol } 20 \mathrm{mg}(\mathrm{n}=12) \\
\text { Placebo }\end{array}$ & $\begin{array}{l}138 \\
180\end{array}$ & $\begin{array}{l}10 \cdot 0 \\
15 \cdot 8\end{array}$ & $<0.01$ \\
\hline $\begin{array}{l}\text { Metoprolol } 50 \mathrm{mg}(\mathrm{n}=11) \\
\text { Placebo }\end{array}$ & $\begin{array}{l}118 \\
174\end{array}$ & $\begin{array}{l}11 \cdot 9 \\
12 \cdot 6\end{array}$ & $<0.001$ \\
\hline $\begin{array}{l}\text { Rate-pressure product }\left(\times 10^{-2}\right) \text { at end of work } \\
\text { Metoprolol } 20 \mathrm{mg}(\mathrm{n}=12) \\
\text { Placebo }\end{array}$ & $\begin{array}{l}157 \\
207\end{array}$ & $\begin{array}{l}13 \cdot 6 \\
18 \cdot 7\end{array}$ & $<0.05$ \\
\hline $\begin{array}{l}\text { Metoprolol } 50 \mathrm{mg}(\mathrm{n}=11) \\
\text { Placebo }\end{array}$ & $\begin{array}{l}146 \\
222\end{array}$ & $\begin{array}{l}13 \cdot 1 \\
20 \cdot 0\end{array}$ & $<0.001$ \\
\hline
\end{tabular}

Conversion factor from Traditional Units to SI Units: $1 \mathrm{mmHg} \approx 0.133 \mathrm{kPa}$.

placebo period than during the period on treatment with metoprolol $50 \mathrm{mg}$ t.d.s.

Nitroglycerin consumption was significantly reduced by metoprolol at both dosage levels, com- pared with the corresponding placebo periods $(P<0.05)$ (Table 2).

A significant improvement was also apparent from the patients' subjective daily assessment of their angina, both with metoprolol $20 \mathrm{mg}$ t.d.s. 
$(P<0.02)$ (Fig. 2) and with the dosage of $50 \mathrm{mg}$ t.d.s. $(P<0.001)$ (Fig. 3).

The general preference at the end of each period showed that 8 patients had a clear preference for metoprolol $20 \mathrm{mg}$ t.d.s. compared with placebo, and 10 patients for metoprolol $50 \mathrm{mg}$ t.d.s. compared with placebo.

\section{B. Cardiovascular effects at rest and during exercise (Tables 3 and 4).}

Case 4 was excluded from this evaluation because he was unable to exercise on the bicycle. Two patients (Cases 2 and 13) did not tolerate placebo treatment, because of worsening of their angina, and were switched over to active drug treatment after a few days. Neither of these patients was able to exercise during the second placebo period.

Mean values for heart rate, blood pressure, and rate-pressure product during exercise are given in in Table 3.

Heart rate Calculations of the mean values showed that metoprolol at both dose levels produced a significant reduction in resting heart rate, heart rate recorded at comparable work load, and heart rate at the end of exercise, compared with placebo. The effect was greater at the higher dose.

Systolic blood pressure measured resting supine, at comparable work load, and at the end of exercise, was also significantly reduced with both doses.

Rate-pressure product was significantly reduced with both doses of metoprolol at comparable work load, and at the end of exercise. The reduction was greater with the dosage of $50 \mathrm{mg}$ t.d.s.

Total work was calculated as the product of work load in Watts and number of minutes of exercise. There was a statistically significant increase in total work with metoprolol at both $20 \mathrm{mg}$ t.d.s. $(P<0.05)$, and $50 \mathrm{mg}$ t.d.s. $(P<0.05)$, compared with placebo (Table 4).
Work load at break point, the highest calculated load tolerated for 6 minutes (Ekelund, Melcher, and Orö, 1974), increased significantly with metoprolol $20 \mathrm{mg}$ t.d.s. $(P<0.05)$ and $50 \mathrm{mg}$ t.d.s. $(P<0.01)$ compared with placebo.

Eight patients increased their total work by 20 per cent or more on the dosage of $20 \mathrm{mg}$ t.d.s. compared with placebo. These patients are regarded as responders to the dosage of $20 \mathrm{mg}$ t.d.s. Three patients increased their total work by more than 20 per cent on the dosage of $50 \mathrm{mg}$ t.d.s. Two patients (Cases 2 and 13) did not perform any exercise test during the second placebo period because of worsening of angina pectoris, and were switched over to metoprolol $50 \mathrm{mg}$ t.d.s. after a few days. These 5 patients are regarded as responders to the dosage of $50 \mathrm{mg}$ t.d.s. Cases 6,12 , and 14 are regarded as responders to the $20 \mathrm{mg}$ t.d.s. but not to $50 \mathrm{mg}$ t.d.s. However, these 3 patients showed a distinct improvement in exercise tolerance when the second placebo period was compared with the first.

The perceived exertion, angina pectoris, dyspnoea, and sensation of fatigue in the legs were not significantly affected, by either dose of metoprolol.

Cardiac volume, calculated as total volume, showed no significant differences at the end of the treatment periods with metoprolol $50 \mathrm{mg}$ t.d.s. or placebo.

\section{Complications and unwanted effects}

Two patients (Cases 2 and 13) did not tolerate the placebo because of worsening of angina pectoris, and were, therefore, given active drug treatment after 2 to 4 days. One patient (Case 4) complained of dizziness on metoprolol $50 \mathrm{mg}$ t.d.s., but when the dose was halved, this symptom disappeared. The frequency of unwanted effects was low and about the same during treatment with metoprolol and placebo.

All 16 patients were included in a long-term tolerance study with unchanged doses of meto-

TABLE 4 Effect of metoprolol on total work and work load at break point

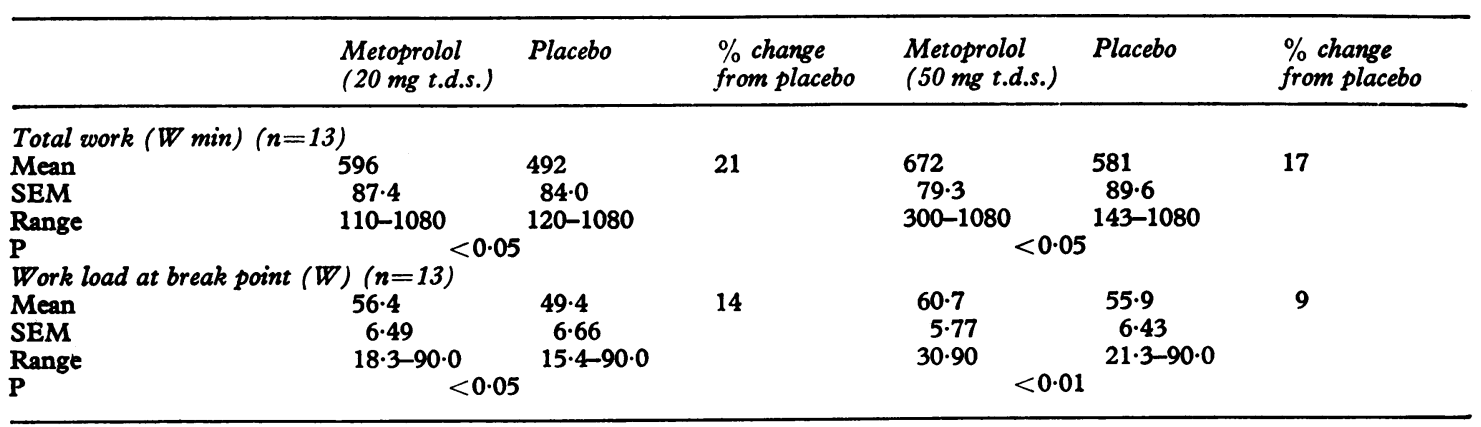


prolol. Thus, one patient had $25 \mathrm{mg}$ t.d.s. and the remainder had $50 \mathrm{mg}$ t.d.s. Patients were examined after $6,12,18$, and 24 months' treatment with metoprolol. The following laboratory investigations were done: haemoglobin, white blood cell count, and ESR; serum creatinine, bilirubin, alkaline phosphatase, AST, ALT, cholesterol, triglycerides, uric acid, and antinuclear factor (ANF).

During the long-term tolerance study, one patient had a non-fatal myocardial infarction. In the whole group no severe unwanted effects were observed and there were no abnormal laboratory findings. Blood pressure and body weight remained unchanged throughout the study.

\section{Discussion}

This study was performed to evaluate the antianginal effect of metoprolol in 16 patients previously treated with alprenolol. As this was one of the first studies with chronic metoprolol treatment in angina pectoris, the study was designed to evaluate response to two dosage levels, with $20 \mathrm{mg}$ t.d.s. always preceding $50 \mathrm{mg}$ t.d.s.

The results of the exercise test show that total work was significantly increased, compared with placebo, by about 20 per cent after both dose levels of metoprolol. The increase in exercise tolerance was largest in the patients who had a decrease or only a very small increase in cardiac volume after metoprolol. Determination of the cardiac volume in combination with exercise tests might thus be of value for evaluating the effect of a beta-receptor blocking agent (Jonsson, Olsson, and Orö, 1973). The increase in exercise tolerance was of the same magnitude as reported by Adolfsson et al. (1974) and was accompanied by a corresponding subjective improvement. The reduction of heart rate and systolic blood pressure was of the same magnitude as in the acute study by Adolfsson et al. (1974).

All the patients were well known to us, having been treated for long periods, were familiar with exercise testing, and could be regarded as having stable angina pectoris. Therefore, only minor differences were expected to appear between the two placebo periods. However, many of the patients showed unexpected improvement during the second placebo period, with both reduction in frequency of angina and increased exercise capacity. This difference in exercise tolerance between placebo periods could be attributed to increased activity and physical fitness resulting from previous treatment. The effect of the exercise testing on exercise capacity could certainly be neglected. This improvement during the second placebo period probably had an unfavourable effect on the apparent results of treatment with $50 \mathrm{mg}$ t.d.s. relative to treatment with $20 \mathrm{mg}$ t.d.s. of metoprolol. Therefore, from the results of the present investigation it is difficult to state which of the two dosage levels used is the optimal one.

However, if only the median and mean values are taken into consideration, there was an improvement during the $50 \mathrm{mg}$ t.d.s. treatment period compared with the $20 \mathrm{mg}$ t.d.s. period. These results suggest that $20 \mathrm{mg}$ t.d.s. is a suitable initial dose of metoprolol, and that many patients derive further benefit from $50 \mathrm{mg}$ t.d.s. In this study, neither of the doses used induced any clinically significant unwanted effects nor were there any abnormal findings in the laboratory tests.

Both the increase in exercise tolerance and the subjective improvement indicate that metoprolol is effective in angina as are other beta-adrenergic blocking agents (Dagenais, Pitt, and Ross, 1971; Adolfsson, Areskog, and Rasmuson, 1971; Hetherington et al., 1973). Furthermore, metoprolol should have advantages resulting from its selective effect on beta ${ }_{1}$-adrenergic receptors, especially in patients with bronchial asthma, and could in special cases be combined with a beta ${ }_{2}$-stimulating agent such as salbutamol or terbutalin (Thiringer and Svedmyr, 1976).

\section{References}

Åblad, B., Carlsson, E., and Ek, L. (1973). Pharmacological studies of two new cardioselective adrenergic betareceptor antagonists. Life Sciences, 12, 107.

Adolfsson, L., Areskog, N.-H., Furberg, C., and Johnsson, G. (1974). Effects of single doses of alprenolol and two cardioselective beta-blockers (H 87/07 and $\mathrm{H} \mathrm{93/26)}$ on exerciseinduced angina pectoris. European fournal of Clinical Pharmacology, 7, 111.

Adolfsson, L., Areskog, N.-H., and Rasmuson, T. (1971). Effects of alprenolol and sorbidnitrate during exercise in patients with coronary insufficiency. European fournal of Clinical Pharmacology, 3, 68.

Borg, G. (1970). Perceived exertion as an indicator of somatic stress. Scandinavian fournal of Rehabilitation Medicine, $2,92$.

Dagenais, G. R., Pitt, B., and Ross, R. S. (1971). Exercise tolerance in patients with angina pectoris. American Fournal of Cardiology, 28, 10.

Ekelund, L.-G., Melcher, A., and Orö, L. (1975). Exercise tolerance in patients with angina pectoris after pentaerytrol trinitrate and alprenolol studied by two different methods. European fournal of Clinical Pharmacology, 8, 309.

Hetherington, D. J., Comerford, M. B., Nyberg, G., and Besterman, E. M. M. (1973). Comparison of two adrenergic beta-receptor blocking agents, alprenolol and propranolol, in treatment of angina pectoris. British Heart fournal, 35, 320.

Jonsson, B., Olsson, A. G., and Orö, L. (1973). Effects of alprenolol on central hemodynamics and exercise tolerance in patients with angina pectoris. Cardiology, 58, 150. 
Kjellberg, S. R., Lönroth, H., and Rudhe, U. (1951). The effect of various factors on the roentgenological determination of the cardiac volume. Acta Radiologica, 35, 413.

Lands, A. M., Luduena, F. P., and Buzzo, H. J. (1967). Differentiation of receptors responsive to isoproterenol. Life Sciences, 6, 2241.

Rose, G. A. (1962). The diagnosis of ischaemic heart pain and intermittent claudication in field surveys. Bulletin of the World Health Organization, 27, 645.

Siegel, S. (1956). Non-Barametric Statistics for the Behavioral Sciences. McGraw-Hill, New York.
Snedecor, G. W., and Cochran, W. G. (1967). Statistical Methods, 6th ed. Iowa State College Press, Ames, Iowa. Thiringer, G., and Svedmyr, N. (1976). Interaction of orally administered metoprolol, practolol and propranolol with isoprenaline in asthmatics. European Fournal of Clinical Pharmacology. In the press.

Requests for reprints to Dr. Lars-Göran Ekelund, Department of Clinical Physiology, Karolinska Sjukhuset, S-104 01 Stockholm 60, Sweden. 